\section{Hva er en klinisk beslutning?}

\author{
Medisinske beslutninger, slik de utspiller seg i dialogen mellom lege og \\ pasient, lar seg identifisere og klassifisere - og dem er det mange av.
}

I tidligere forskning på medisinske beslutningeri lege-pasient-konsultasjoner har man lagt vekt på samvalg (shared decision-making) i enkeltbeslutninger, og generelt er det rapportert liten grad av pasientmedvirkning.

I en kvalitativ studie av videofilmede lege-pasient-konsultasjoner fra Akershus universitetssykehus utviklet vi en taksonomi for å identifisere og klassifisere alle typer klinisk relevante beslutninger. Taksonomien består av ti kategorier som skiller mellom typer beslutninger og tre kategorier som beskriver en tidsdimensjon.

Ved anvendelse av taksonomien i analyse av 380 konsultasjoner fant vi for det første at medisinske beslutninger formidles i et høyt antall, det var gjennomsnittlig 13 beslutninger per konsultasjon. Videre fant vi at beslutninger spenner over en lengre tidsramme enn konsultasjonen varer og at de gjerne var fattet ved at flere personer, som oftest helsepersonell, hadde tatt del i beslutningsprosessen. Dette funnet kan være med på å forklare at sykehuspasienter i liten grad blir inkludert i beslutningsprosessene.

Innholdskodingen av materialet har gitt en presis og detaljert beskrivelse av klinisk relevante beslutninger på tvers av kliniske spesialiteter, konsultasjonstyper, leger og lege-pasient-møter. Taksonomien kan være nyttig i fremtidige studier der man tar sikte på å vurdere kvaliteten av medisinske beslutninger ut fra grad av pasientmedvirkning, pasientsikkerhet, profesjonalitet og overensstemmelse med kunnskapsbasert praksis.

\section{Eirik Hugaas Ofstad}

eirikofstad@gmail.com

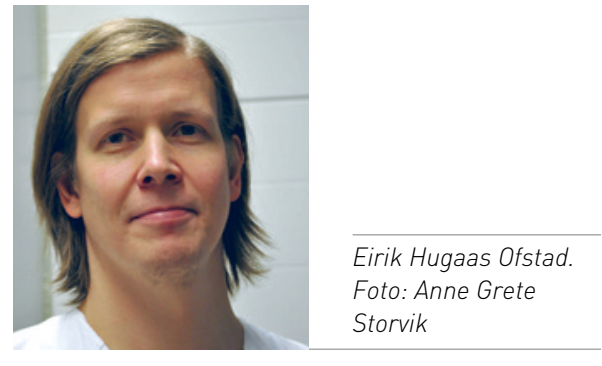

Disputas

Eirik Hugaas Ofstad disputerte for ph.d.-graden ved Universitetet i Oslo 18.9. 2015. Tittelen på avhandlingen er Medical decisions in 372 hospital encounters.

\title{
Periodisk febersyndrom hos barn
}

\section{Periodisk febersyndrom er en viktig differensialdiagnose hos barn med residiverende feberepisoder, også når disse opptrer i første leveår.}

Periodisk febersyndrom (PFAPA) er den vanligste autoinflammatoriske sykdommen hos barn. Sykdommen kjennetegnes av regelmessige, korte og selvbegrensende feberepisoder som opptrer omtrent hver fjerde uke. Under feberturene har barna store lymfeknuter på halsen, sår i munnslimhinnen og betennelse i svelgslimhinner og tonsiller. Periodisk febersyndrom er en godartet og selvbegrensende sykdom, men episodene er svært belastende for barnet og familien.

Fra 2004 er alle barn diagnostisert med periodisk febersyndrom ved Barne- og ungdomsklinikken ved Stavanger universitetssjukehus blitt vurdert og fulgt opp systematisk. Doktoravhandlingen min bygger på tre artikler der vi beskriver insidens og sykdomsforløp, funn i tonsillvev og målinger av cytokiner og leukocytter i blodet hos barn med periodisk febersyndrom.

Vi beregnet årlig insidens av periodisk febersyndrom til 2,3 per 10000 barn under fem år, og fant at median debutalder var 11 måneder. Feberepisodene ved periodisk febersyndrom var assosiert med rask stigning i nivået av nøytrofile granulocytter, monocytter og interleukin-6 og kjemokinene CXCL10 og CCL4 i serum. Ved histologisk undersøkelse av tonsillene fant vi uspesifikk reaktiv lymfoid hyperplasi, og ved immunhistokjemisk analyse av tonsillene fant vi færre CD8-positive celler i germinalsentre hos barn med periodisk febersyndrom enn hos kontrollbarn operert for tonsillhypertrofi.

Cytokinmønster ved feberepisoder og studier av ulike celletyperi tonsillene kan bidra til å forstå etiologien til periodisk febersykdom. Leger som vurderer barn med tilbakevendende feberepisoder, bør være kjent med tilstanden.

Jostein A. Førsvoll jforsvoll@gmail.com

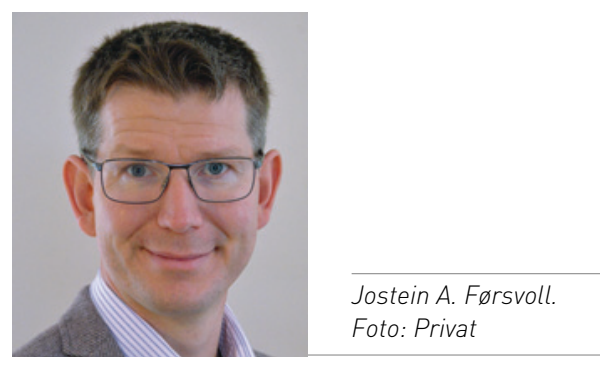

Disputas

Jostein A. Førsvoll disputerte for ph.d.-graden ved Universitetet i Bergen 11.9. 2015. Tittelen på avhandlingen er: The periodic fever, aphthous stomatitis, pharyngitis and cervical adenitis syndrome in children. Clinical and immunological aspects. 